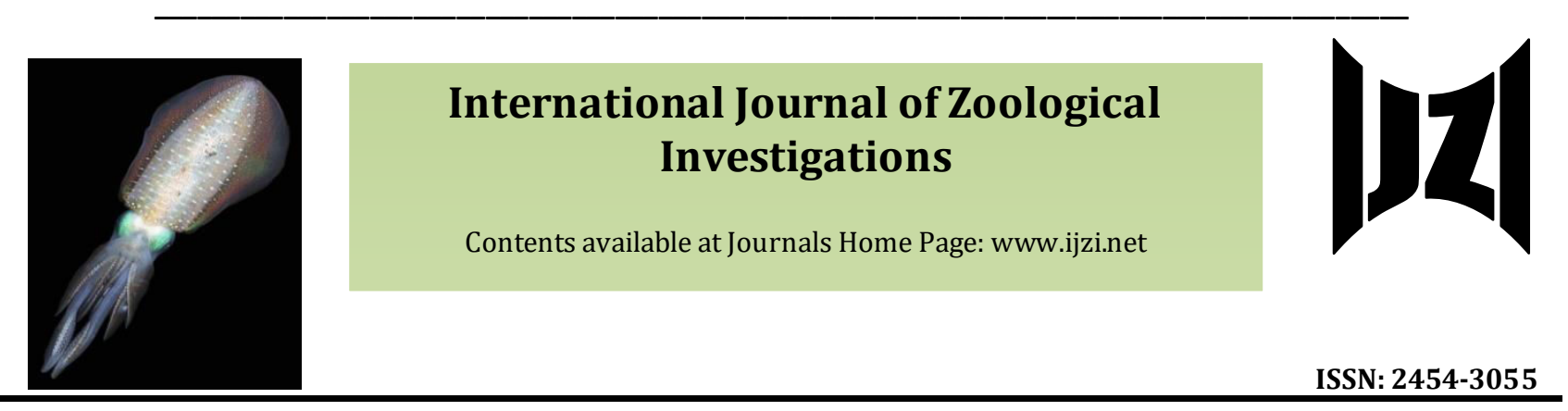

\title{
Effect of Cypermethrin 25\% EC, an Endocrine Disrupting Chemical and pH on Reproductive Health of Puntius javanicus
}

\author{
Roy Tushar Kanti ${ }^{*}$ and Saha Samir Kumar² \\ 1Department of Zoology, Mrinalini Datta Mahavidyapith,Vidyapith Road, Birati, Kolkata 700051, India \\ 2Department of Zoology, West Bengal State University, Berunanpukuria, PO: Malikapur, Kolkata 700126, India \\ *Corresponding Author
}

Received: $14^{\text {th }}$ April, 2021

Accepted: 17th May, 2021

Published online: 26 $6^{\text {th }}$ May, 2021

https://doi.org/10.33745/ijzi.2021.v07i01.018

\begin{abstract}
In the present study an attempt has been made to investigate the combined effect of sub-lethal dose of Cypermethrin 25\% EC and pH on histoarchitecture of gonads and GnRH hormone of Puntius javanicus. 96h $\mathrm{LC}_{50}$ value was determined by method of Karber and it was found to be $3.65 \mu \mathrm{g} / \mathrm{L}$ for Puntius javanicus. Adult fish were exposed to sub-lethal concentration $(0.365 \mu \mathrm{g} / \mathrm{L})$ of Cypermethrin $25 \% \mathrm{EC}$ in different $\mathrm{pH}$ of water, i.e. $\mathrm{pH} 5, \mathrm{pH} 6$, pH 7, pH 8.5 and pH 9.5 for 15 days. Significant histopathological alterations were found in testis and ovary of the fish subjected to sub-lethal concentration of cypermethrin $25 \%$ EC. Significant decrease $(p<0.001)$ of GnRH concentration was recorded in pesticide exposed fishes. Significantly more histopathological alterations of gonads and decrease of $\mathrm{GnRH}$ concentration were recorded when fish were exposed to sub-lethal concentration of cypermethrin 25\% EC in $\mathrm{pH} \mathrm{5,} \mathrm{pH} 6$ and $\mathrm{pH}$ 9.5, compared to fish exposed to sub-lethal concentration of cypermethrin 25\% EC in pH 7 water. A significant increase of GnRH concentration $(\mathrm{p}<0.05)$ was documented in fishes exposed to sub-lethal concentration of cypermethrin in $\mathrm{pH}$ 8.5, compared to fishes exposed to sub-lethal concentration of cypermethrin in $\mathrm{pH} 7$ and the concentration is found to be almost equal to the control group (pH 7, without toxicant). At this medium histoarchitecture of testis and ovary retained almost normal histology with least alterations.
\end{abstract}

Keywords: Cypermethrin, Histopathology, Histoarchitecture, GnRH, Sub-lethal concentration, Puntius javanicus Citation: Roy Tushar Kanti and Saha Samir Kumar: Effect of cypermethrin 25\% EC, an endocrine disrupting chemical and pH on reproductive health of Puntius javanicus. Intern. J. Zool. Invest. 7 (1): 217-229, 2021.

https://doi.org/10.33745/ijzi.2021.v07i01.018

\section{Introduction}

Use of pesticides has been increased many fold to protect the crop from pests and to increase the production of crop (Aktar et al.,
2009; Chandola et al., 2011; Gupta et al., 2012; Srivastav et al., 2020; Tudi et al., 2021). The natural water reservoirs are getting polluted 
all over the world due to injudicious use of pesticides (Gilliom et al., 2007; Ngidlo, 2013). Pesticides affect overall ecosystem, especially the aquatic ecosystem, leading to undesirable mortality of aquatic flora and fauna, mainly fishes (Kumari, 2005; Gupta et al., 2013; Srivastav et al., 2020). Synthetic pyrethroids have been introduced over the past few decades for agricultural and domestic use. Pyrethroid pesticides adversely affect fish health (Sanchez- Fortun et al., 2005). The biochemical changes in different organs/tissues of fish due to toxicity stress of heavy metals and pesticides have been reported by number of workers (Khan, 1982; Balint et al., 1995; Das et al., 1999; Rao et al., 2000; Khare et al., 2002 ). In fishes pyrethroid is metabolized and eliminated from the body comparatively more slowly than in mammals or birds (Bradbury et al., 1989).

On the other hand many abiotic factors have been reported to affect the health of the fish. Abiotic factors such as temperature, $\mathrm{pH}$, water column length, turbidity, salinity, alkalinity of water etc. are reported to have profound effect on the reproductive success of the fish (Wilson, 1956; Herzig and Winkler, 1986; Ikuta and Kitamura, 1995; Ernst et al., 2005; Tiffany et al., 2009). Amongst all these abiotic factors, $\mathrm{pH}$ is one of the most important factors affecting aquatic life. Levels of $\mathrm{pH} 4$ constitute acidic condition lethal to fish (Ikuta et al., 1992).

Hormones play a critical role in reproduction. Gonadotropin releasing hormone $(\mathrm{GnRH})$ is released from hypothalamus and stimulates the secretion of gonadotropins from the pituitary. Gonadotropins stimulate gonads to secret steroid hormones leading to the reproductive success. Secretion of hormones such as gonadotropin releasing hormone $(\mathrm{GnRH})$ in general is lowered by the pesticidal effect, leading to cessation of gametogenesis, vitellogenesis, oocyte maturation, ovulation, spermiation etc. (Lal, 2007).

In the present study we evaluated the combined effects of $\mathrm{pH}$ and cypermethrin $25 \%$ EC (cypercid 25) on gonads and reproductive hormone (GnRH) of Puntius javanicus.

\section{Materials and Methods}

The healthy freshwater Puntius javanicus (100 $\pm 5 \mathrm{~g} ; 17-19 \mathrm{~cm}$ ) were obtained from a local fish reservoir of Barasat, North 24 Parganas, West Bengal, India. The fish were treated with potassium permanganate solution $(0.5 \% \mathrm{w} / \mathrm{v})$ for $1 \mathrm{~min}$ to remove any dermal adherent. Fishes were acclimatized for 2 weeks in glass aquarium (500 L) containing de-chlorinated and aerated water at room temperature $32 \pm$ 1.0 C). During acclimatization period commercial food pellet was provided to fishes. Dead fish were removed instantly to keep the water clean. Food was not provided to the fish $24 \mathrm{~h}$ prior to toxicity testing and they were starved during the period of experiment. Characteristics of water were measured prior to the experiment with water quality test kit of Aquaponics (Table 1).

Table 1: Water quality parameters

\begin{tabular}{|c|c|}
\hline Parameters & Range \\
\hline Temperature & $31-33 \mathrm{C}$ \\
\hline $\mathrm{pH}$ & 7.3-7.5 \\
\hline Dissolved oxygen & $\begin{array}{l}6.1-6.7 \mathrm{mg} / \mathrm{L} \\
\text { (average) }\end{array}$ \\
\hline Nitrate & $0.18 \mathrm{mg} / \mathrm{L}$ (average) \\
\hline Free carbon dioxide & $4.5 \mathrm{mg} / \mathrm{L}$ \\
\hline Alkalinity & $\begin{array}{c}118-132 \mathrm{mg} / \mathrm{L} \text { (as } \\
\text { CaCO3) }\end{array}$ \\
\hline Total hardness & $\begin{array}{c}108-116 \mathrm{mg} / \mathrm{L} \text { (as } \\
\text { CaCO3) }\end{array}$ \\
\hline
\end{tabular}




\section{Toxicity assay:}

Water quality was maintained according to the APHA. Six glass aquaria of $40 \mathrm{~L}$ capacity were filled with de-chlorinated and aerated water. Ten fish (100 $\pm 5 \mathrm{~g}$; 17-19 cm) were placed in each of the six aquaria. Cypercid 25 was added at 1, 2, 3, 4, 5 and $6 \mu \mathrm{g} / \mathrm{L}$ concentration in different aquaria. Water of aquaria was changed daily and pesticide concentrations were restored. Fish kept into the pesticide free medium acted as control. The test was performed for $96 \mathrm{~h}$ treatment period and dead fish were removed as soon as possible. The number of dead fish per group was recorded against the time of their death as specified by Sprague (1969). Method of Karber as adopted by Dede and Kaglo (2001) was used to calculate the $96 \mathrm{~h} \mathrm{LC}_{50}$ value of cypercid 25.

\section{Histopathology:}

The fish were assigned to six groups, each group having ten specimens (Table 2). $\mathrm{pH}$ regulation of water was done by using sodium hydroxide and hydrochloric acid. The water of aquaria was changed daily. Different concentrations of cypercid 25 and different $\mathrm{pH}$ were restored daily. After 15 days of exposure to the experimental condition both control and test fishes were taken out of the water and anaesthetized with mild dose of Benzocaine (Larid and Oswald, 1975). The fish were dissected in Ringer's saline to extirpate the gonads. Testes and ovaries were sliced and fixed in Neutral buffered formalin. After dehydration, tissue sections were cut at 4-6 $\mu \mathrm{m}$ and stained with hematoxylin and eosin and photomicrographed by MAGNUS MLX-TR Trinocular microscope and Dewinter Digi Eye Camera.

\section{Determination of GnRH:}

Brain tissues were extirpated and rinsed with $1 \mathrm{x}$ PBS, homogenized in $1 \mathrm{ml}$ of $1 \mathrm{x}$ PBS and stored overnight at $-20 \mathrm{C}$. After 2 freeze-thaw cycles tissue was centrifuged for 5 min at $5000 \mathrm{x}$ g at 2-8 C. Supernatant was assayed immediately. ELISA was performed as directed by protocol given by the CUSABIO as per the detection range $0.1 \mathrm{ng} / \mathrm{ml}-20 \mathrm{ng} / \mathrm{ml}$ with a sensitivity of $0.5 \mathrm{ng} / \mathrm{ml}$. GnRH was quantified by ELISA plate reader (TRANSASIA) at $450 \mathrm{~nm}$ wavelength. All determinations were done in triplicate.

Statistical analysis:

Data were presented as mean \pm standard error. Apart from descriptive statistics of the outcome variables, appropriate multivariate statistic such as One-way Anova, LSD was done with Minitab, version 17 Software to understand the causal relationship between parameters.

\section{Results}

Toxicity test:

No mortality was recorded in the control group. Fishes were found to be healthy. However, at 1, 2, 3, 4, 5 and $6 \mu \mathrm{g} / \mathrm{L}$ concentrations of cypercid 25, the per cent mortality were $10,20,40,50,70$ and 100 per cent, respectively (Table 3). $96 \mathrm{~h} \mathrm{LC}_{50}$ of cypercid 25 was calculated and it was found as $3.65 \mu \mathrm{g} / \mathrm{L}$ for Puntius javanicus (Table 4).

Testis:

The normal histology of testis of Puntius javanicus show seminiferous tubule with distinct, intact, thin fibrous wall. Healthy leydig cells were also seen. Tubules showed scattered tubular cells (Fig. 1a). Testis 
Table 2: Experimental groups

\begin{tabular}{|l|l|l|}
\hline \multirow{2}{*}{$\begin{array}{l}\text { 10 fishes/group } \\
\text { Exposure period: } 15 \text { days }\end{array}$} & Group & Parameters \\
\cline { 2 - 3 } & 1 (Control) & pH 7 with no Cypermethrin \\
\cline { 2 - 3 } & 2 & $\mathrm{pH7}+$ Sublethal concentration Cypermethrin \\
\cline { 2 - 3 } & 3 & $\mathrm{pH} 5+$ Sublethal concentration Cypermethrin \\
\cline { 2 - 3 } & 4 & $\mathrm{pH}$ + Sublethal concentration Cypermethrin \\
\cline { 2 - 3 } & 5 & $\mathrm{pH} 8.5$ + Sublethal concentration Cypermethrin \\
\cline { 2 - 3 } & 6 & $\mathrm{pH} 9.5+$ Sublethal concentration Cypermethrin \\
\hline
\end{tabular}

exposed to sub-lethal dose of cypercid 25 at pH 7 showed destroyed tubular wall, distorted leydig cell and swollen seminiferous tubule. Intertubular vacuolization and inflammatory cell infiltration was recorded (Fig. 1b). Testis subjected to sub-lethal dose of cypercid 25 at pH 6 and 5 shows much damage of testicular tissues. Swollen seminiferous tubules, inflammation leading to necrosis of the tissue, inter-tubular vacuolization was much prominent. Condensations of tubular cells were seen (Figs. 1c, 1d). Testis exposed to sub-lethal concentration of cypercid 25 at $\mathrm{pH}$ 9.5 showed distorted tubular epithelium, condensation of tubular cells, intertubular vacuolation, and distorted leydig cell (Fig. 1e). However, less abnormalities were documented in tesits subjected to sub-lethal dose of cypercid 25 at pH 8.5 (Fig. 1f). Vacuolization as well as condensation of tubular cells was not so frequent. Seminiferous tubules were found to be much definite in shape. Small scale infiltration of inflammatory cells was documented.

Ovary:

Normal histology of ovary of Puntius javanicus. revealed four stages (I, II, III and IV) of oocytes. Oocyte I had the smallest diameter and oocyte IV had the largest. Few atretic
(AT) cells were found. Intact ovigerous lamellae (OL) and follicular lining (FL) were recorded. Oocyte III cells were found to have provitelline nucleoli (PN) and euvitelline nucleoli (EU) and obvious nuclei (N). Yolk vacuoles (YV) were noticed in Oocyte IV. Among all oocytes oocyte III cells were dominant (Fig. 2a). Ovaries exposed to sublethal dose of cypercid 25 at $\mathrm{pH} 7$ shows increased damage of oocytes. Damage includes adhesion (AD) of oocytes, some karyoplasmic clumping (CK), and increased number of atretic (AT) cells. Nuclear retraction (NR) was recorded in Oocyte III. Lifting of the ovigerous lamellae (LOL), Provitelline (PN) and Euvitelline (EU) nucleoli were still found in oocyte III. Size of all types of oocytes were decreased. Patches of macrophage (MI) was seen indicating inflammation (Fig. 2b). Ovary of Puntius javanicus subjected to sub-lethal dose of cypercid 25 at pH 6 showed extensive damage of ovigerous lamellae (OL). Numerous atretic cells (AT) were found. Adhesion (AD) could be seen easily. Follicular damage (D), patches of macrophage (MI) and damaged stroma (DS) were noticed. Nuclear retraction (NR) as well as cytoplasmic retraction (CR) was noticed in oocyte III. Oocyte IV was almost absent. An expelled nucleus (EN) was also noticed (Fig. 
Table 3: Toxicity testing of Cypercid 25 on Puntius javanicus for $96 \mathrm{~h}$

\begin{tabular}{|c|c|c|c|c|c|c|}
\hline \multirow{2}{*}{$\begin{array}{l}\text { Concentration } \\
(\mu \mathrm{g} / \mathrm{L})\end{array}$} & \multicolumn{4}{|c|}{ No. of alive fish } & \multirow{2}{*}{$\begin{array}{c}\% \text { survival } \\
\text { at } 96 \mathrm{~h}\end{array}$} & \multirow{2}{*}{$\begin{array}{c}\% \text { Mortality } \\
\text { at } 96 \mathrm{~h}\end{array}$} \\
\hline & $24 \mathrm{~h}$ & $48 \mathrm{~h}$ & $72 \mathrm{~h}$ & $96 \mathrm{~h}$ & & \\
\hline 0 (Control) & 10 & 10 & 10 & 10 & 100 & 0 \\
\hline 1 & 10 & 10 & 10 & 9 & 90 & 10 \\
\hline 2 & 10 & 10 & 9 & 8 & 80 & 20 \\
\hline 3 & 10 & 10 & 7 & 6 & 60 & 40 \\
\hline 4 & 9 & 8 & 5 & 5 & 50 & 50 \\
\hline 5 & 7 & 5 & 5 & 3 & 30 & 70 \\
\hline 6 & 5 & 2 & 0 & 0 & 0 & 100 \\
\hline
\end{tabular}

Table 4: Determination of $\mathrm{LC}_{50}$ value of Cypercid 25 for Puntius sp. for $96 \mathrm{~h}$

\begin{tabular}{|c|c|c|c|c|c|}
\hline $\begin{array}{c}\text { Concentration } \\
(\mu \mathrm{g} / \mathrm{L})\end{array}$ & $\begin{array}{c}\text { Concentration } \\
\text { difference }\end{array}$ & $\begin{array}{c}\text { Number of } \\
\text { alive fish }\end{array}$ & $\begin{array}{c}\text { Number of } \\
\text { dead fish }\end{array}$ & $\begin{array}{c}\text { Mean } \\
\text { death }\end{array}$ & $\begin{array}{c}\text { Mean death X } \\
\text { concentration } \\
\text { difference }\end{array}$ \\
\hline 0 (Control) & -- & 10 & 0 & 0 & 0 \\
\hline 1 & 1 & 9 & 1 & 0.5 & 0.5 \\
\hline 2 & 1 & 8 & 2 & 1.5 & 1.5 \\
\hline 3 & 1 & 6 & 4 & 2.5 & 2.5 \\
\hline 4 & 1 & 5 & 5 & 4.5 & 4.5 \\
\hline 5 & 1 & 3 & 7 & 6 & 6 \\
\hline 6 & 1 & 0 & 10 & 8.5 & 8.5 \\
\hline
\end{tabular}

2c). Ovary of treated fish with sub-lethal dose of toxicant at $\mathrm{pH} 5$ exhibited extensive damage of ovigerous lamellae (OL). Large numbers of atretic cells (AT) were found. Adhesion (AD) was profound. Follicular damage (D), patches of macrophage (MI) were seen everywhere. Nuclear retraction (NR) as well as cytoplasmic retraction (CR) was noticed in oocyte III. Oocyte IV was almost absent. An expelled nucleus (EN) was also noticed. Size of all types of oocytes decreased (Fig. 2d). Ovary treated with sub-lethal dose of toxicant at pH 9.5 showed all types of oocytes, nuclear retraction (NR) was seen in oocyte III. Atretic cells (AT) were recorded in moderate numbers. Lifting of ovigerous lamella (LOL) and macrophage infiltration (MI) was found. Adhesion (AD) was prominent. Size of all oocytes found to be almost the same as control (Fig. 2e). Ovary of Puntius javanicus treated with sub-lethal dose of cypercid 25 at $\mathrm{pH} \quad 8.5$ exhibited damage of ovigerous lamellae (OL). Morderate number of atretic cells (AT) was found. Patches of macrophage 


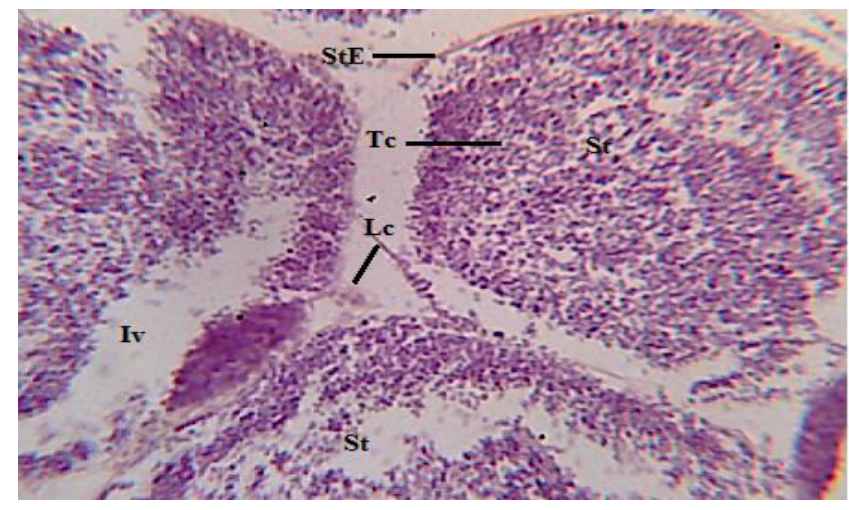

Fig. 1a: Testis of control Puntius javanicus showing normal histology (H and E X 400), St-Seminiferous tubule, St ESeminiferous tubule epithelium, Tc- Scattered tubular cells, LcLeydig cells. Iv-Intertubular vacuolation

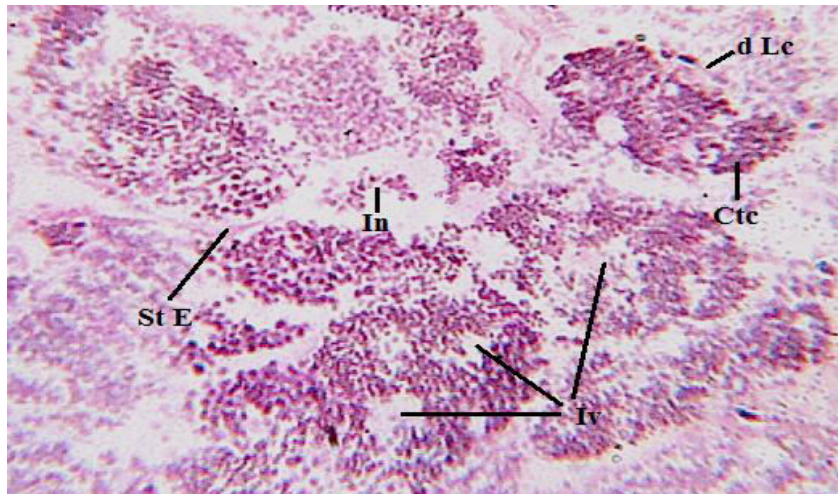

Fig. 1c: Testis of Puntius javanicus treated with sub-lethal dose of Cypermethrin 25\% EC at pH 6 for 15 days (H and E X 400), St ESeminiferous tubular epithelium, In- Inflamation, Ctc- Condensation of tubular cells, D Lc- Distorted leydig cell.

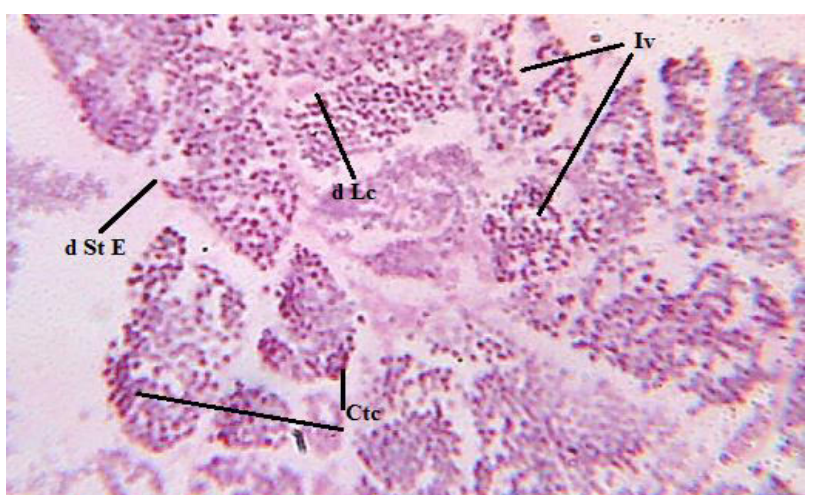

Fig. 1e: Testis of Puntius javanicus treated with sub-lethal dose of Cypermethrin 25\% at pH 9.5 for 15 days (H and E X 400), d St E- distorted tubular epithelium, Ctc- Condensation of tubular cells, Iv- Intertubular vacuolation, D Lc- Distorted leydig cell.

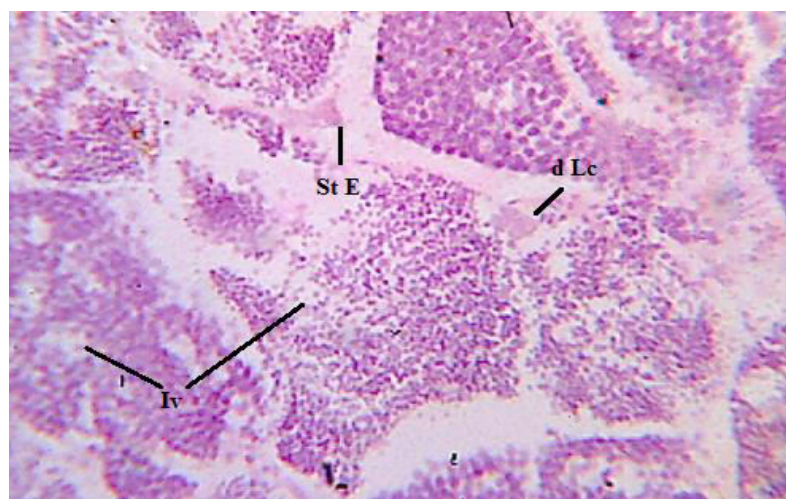

Fig. 1b: Testis of Puntius javanicus treated with sub-lethal dose of Cypermethrin 25\% EC at pH 7 for 15 days (H and E X 400), d Lc- distorted Leydig cell, Iv- Intertubular vacuolation, St Eseminiferous tubular epithelium

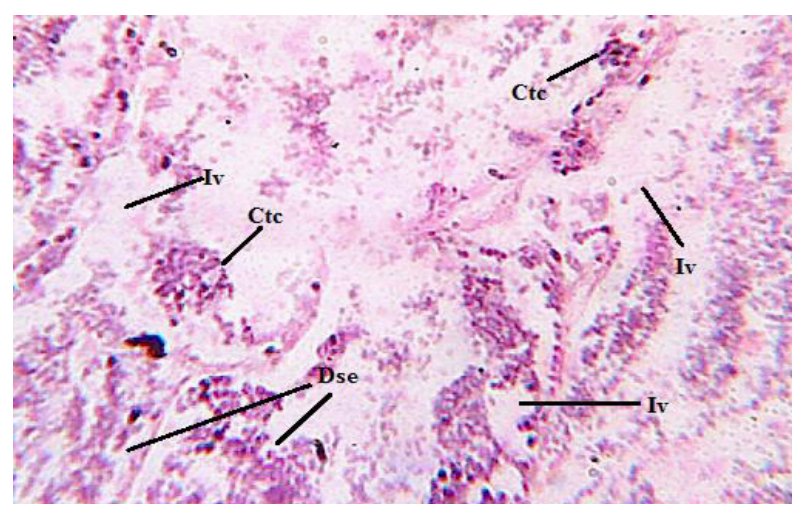

Fig. 1d: Testis of Puntius javanicus treated with sub-lethal dose of Cypermethrin 25\% EC at pH 5 for 15 days (H and E X 400), Dse- Inflammation and distortion of seminiferous epithelium, Ctc- Condensation of tubular cells, Iv- Intertubular vacuolation

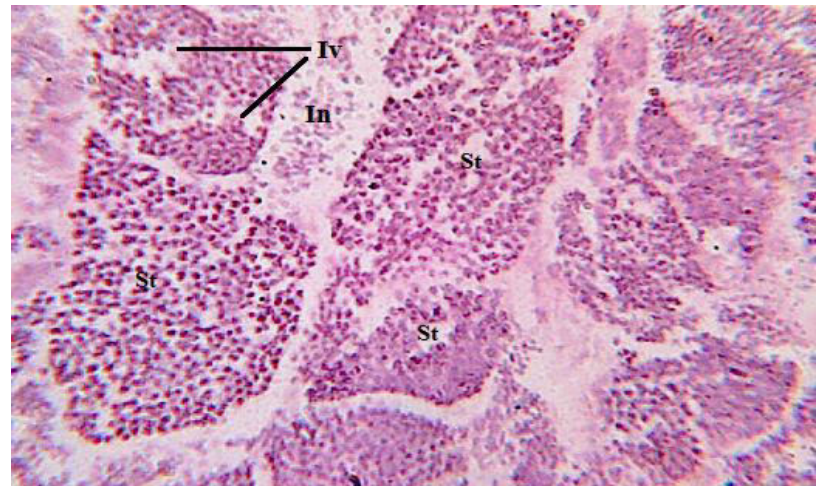

Fig. 1f: Testis of Puntiusjavanicus treated with sub-lethal dose of Cypermethrin 25\% EC at pH 8.5 for 15 days (H and E X 400), StSeminiferous tubule, In- Inflamation, Iv- Inter tubular vacuolation. 


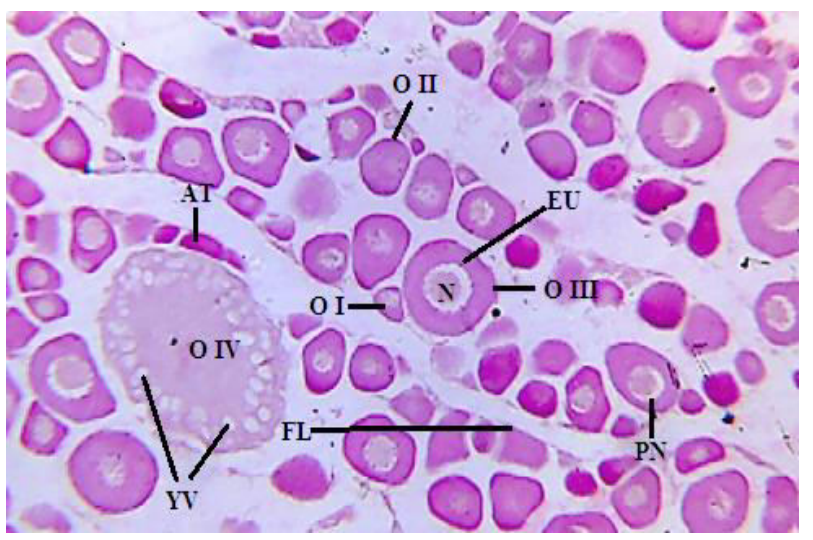

Fig. 2a: Ovary of control Puntius javanicus showing normal histology (H and E X 100). O I- oocyte I, O II- oocyte II, O IIIoocyte III, O IV- oocyte IV, N- nucleus, PN- Provitelline and EUeuvitelline nucleoi, FL- follicular linings YV- yolk vacuoles . AT Atretic cells.

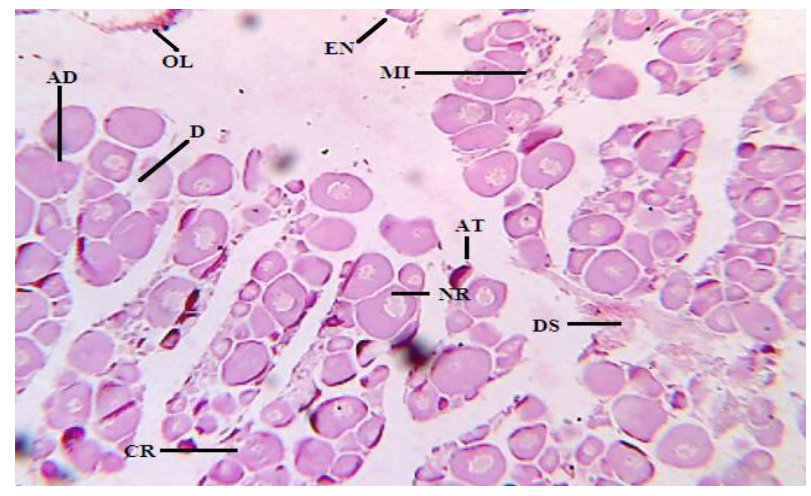

Fig. 2c: Ovary of Puntius javanicus treated with sub-lethal dose of Cypermethrin 25\% EC at pH 6 for 15 days (H and E X 100).OLOvigerous lamellae, AT- Atretic cells, AD- Adhesion, D- Follicular damage, MI- Macrophage infiltration, DS- Damaged stroma, NRNuclear retraction, CR- Cytoplasmic retraction, EN- Expelled nucleus

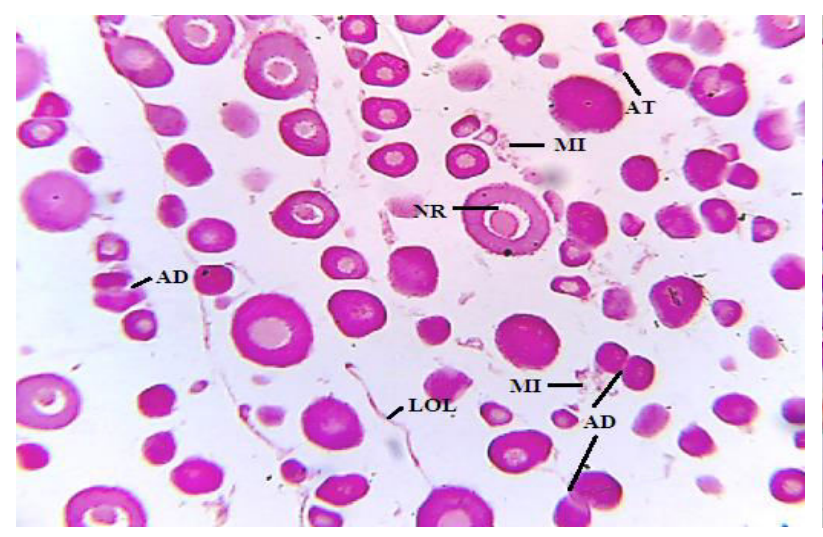

Fig. 2e: Ovary of Puntius javanicus treated with sub-lethal dose of Cypermethrin 25\% EC at pH 9.5 for 15 days (H and E X 100). NRNuclear retraction, AT- Atretic cells, LOL- Lifting of ovigerous lamellae, MI- Macrophage, AD- Adhesion.

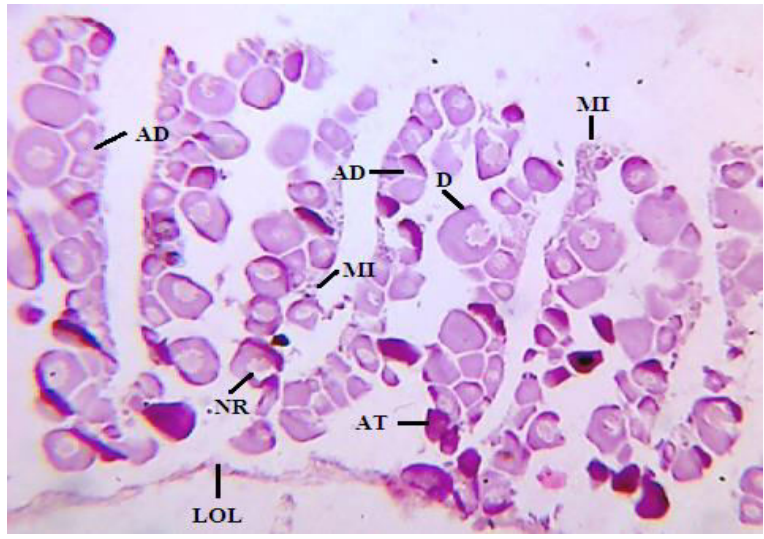

Fig. 2b: Ovary of Puntius javanicus treated with sub-lethal dose of Cypermethrin 25\% EC at pH 7 for 15 days (H and E X 100). LOL-lifted ovigerous lamellae, NR- Nuclear retraction, ATAtretic cell, MI- Macrophage infiltration, D-Damaged oocyte

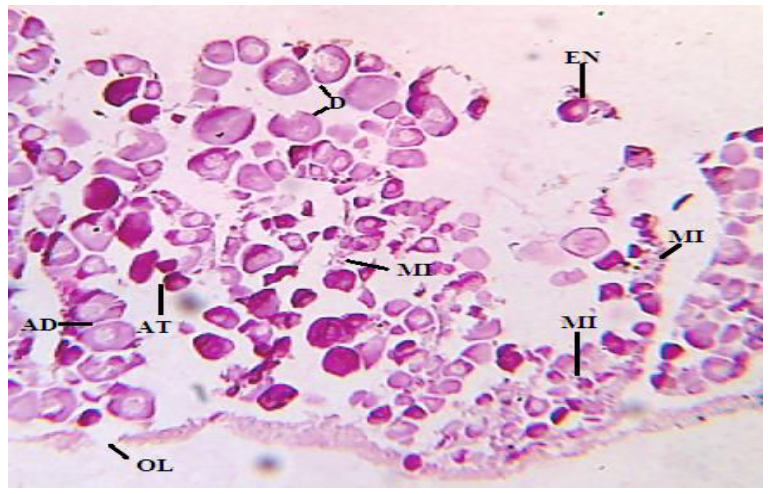

Fig. 2d: Ovary of Puntius javanicus treated with sub-lethal dose of Cypermethrin 25\% EC at pH 5 for 15 days (H and E X 100). OL,- Ovigerous lamellae, AT- Atretic cells, AD- Adhesion, DFollicular damage, MI- Macrophage infiltration, NR- Nuclear retraction, CR- Cytoplasmic retraction, EN- Expelled nucleus.

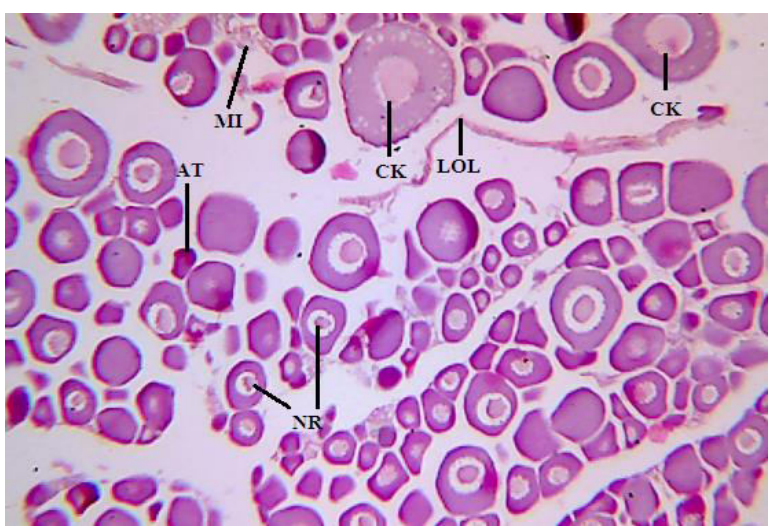

Fig. 2f: Ovary of Puntius javanicus treated with sub-lethal dose of Cypermethrin 25\% EC at pH 8.5 for 15 days (H and E X 100). LOL- Lifting ovigerous lamellae, AT- Atretic cells, MIMacrophage infiltration, NR- Nuclear retraction in oocyte III, CK- Karyoplasmic clumping. 
(MI) were seen. Nuclear retraction (NR) was noticed in oocyte III. Karyoplasmic clumping (CK) was seen in oocyte IV. Size of all oocytes found to be same as control (Fig. 2f).

\section{GnRH concentration:}

Fish exposed to sublethal concentration of cypercid 25 at different $\mathrm{pH}$ exhibited significant $\quad(\mathrm{p}<0.001) \quad$ variation of concentration of GnRH (Table 5). GnRH level in acidic water $(\mathrm{pH} 6$ and $\mathrm{pH} 5)$ with toxicant showed much lower concentration $(0.400 \pm 0.012 \mu \mathrm{g} / \mathrm{ml}$ and $0.517 \pm 0.018 \mu \mathrm{g} / \mathrm{ml}$, respectively) in comparison to the fish exposed to the basic water $\mathrm{pH} 8.5$ and $\mathrm{pH}$ 9.5) with toxicant $(1.020 \pm 0.057 \mu \mathrm{g} / \mathrm{ml}$ and $0.743 \pm 0.018 \mu \mathrm{g} / \mathrm{ml}$, respectively) (Table 6). Significant $((\mathrm{p}<0.05)$ decrease of $\mathrm{GnRH}$ was recorded in fish exposed to cypercid 25 and gradual decrease was noticed in acidic ( $\mathrm{pH} 5$ and $\mathrm{pH}$ 6) and alkaline medium ( $\mathrm{pH}$ 9.5). However, in $\mathrm{pH} 8.5$, concentration of GnRH increased significantly $(\mathrm{p}<0.05)$ (Fig. 3). The $\mathrm{GnRH}$ concentration at $\mathrm{pH} 8.5$ with toxicant $(1.020 \pm 0.057 \mu \mathrm{g} / \mathrm{ml})$ was found to be near the concentration of $\mathrm{GnRH}$ of fish exposed to $\mathrm{pH} 7$ without toxicant $(1.150 \pm 0.029 \mu \mathrm{g} / \mathrm{ml})$ (Table 7).

\section{Discussion}

In the present study $96 \mathrm{~h} \mathrm{LC}_{50}$ values of cypercid 25 for Puntius javanicus was recorded as $3.65 \mu \mathrm{g} / \mathrm{L}$. For various pyrethroids the range of $96 \mathrm{hr} \mathrm{LC}_{50}$ value has been reported to be below $10 \mu \mathrm{g} / \mathrm{L}$ (Smith and Stratton, 1986; Bradbury and Coats, 1989). Several investigators have reported $96 \mathrm{~h} \mathrm{LC}_{50}$ values of cypermethrin in different fish species: $7.2 \mu \mathrm{g} / \mathrm{L}$ for Heteropneustes fossilis (Mishra et al., 2002); 0.9-1.1, 1.2, 0.5, 0.4 and $2.2 \mu \mathrm{g} / \mathrm{L}$ for Cyprinus carpio, Salmo trutta, Salmo gairdneri, Scardinius erythropthalmus, and Tilapia nilotica, respectively (Bradbury and Coats, 1989).

Reproductive function analysis is very important to determinine the dynamics of fish populations (Mekkawy and Hassan, 2011; Ojaveer et al., 2015). Exposure of pollutants in aquatic medium adversely affect fish reproduction leading to reproductive impairment (Aquezar et al., 2006; Ebrahimi and Taherianfrad, 2011; Gerbron et al., 2014; Zhang et al., 2016). Testis of fish exposed to sub-lethal dose of cypercid 25 at $\mathrm{pH} 7$ shows destroyed tubular wall, distorted leydig cell and swollen seminiferous tubules. Intertubular vacuolization and inflammatory cell infiltration are suggestive of initiation of necrosis. When fish were subjected to the acidic medium ( $\mathrm{pH} 5$ and $\mathrm{pH}$ 6) and in extreme basic medium (pH 9.5), above mentioned damages were found to be more profound. However, in $\mathrm{pH} 8.5$ fish were found to retain normal architecture of testis with few abnormalities. Gross inflammation was found in testicular tissue in the present study. In aquatic animals subjected to environmental toxicants testicular inflammation was found to be most obvious response (Sokal et al., 1985; Zutshi and Murthy, 2001). Detrimental effect of cypermethrin on the gonadal morphology and histology was reported by several workers. A few of them are -- decreased spermatozoa and abnormal testicular connective tissue in Japanese medaca Oryzias latipes (Yokota et al., 2000), loss of testicular structure in Japanese medaca Oryzias latipes (Metcalfe et al., 2001), gonad histology alteration in adult common carp Cyprinus carpio (Mardich et al., 2007). In Oreochromis mossambicus BHC exposure caused hyperplastic changes in both primary and secondary spermatocytes (Pandey and Shukla, 1980). Likewise hyperplasia and vacuolization 
Table 5: One-way Anova for GnRH concentration in experimental fish, Puntius javanicus

\begin{tabular}{|l|r|r|r|r|c|}
\hline & Sum of Squares & df & Mean Square & F & Sig. \\
\hline Between Groups & 1.238311111 & 5 & 0.247662 & 101.0866 & 0.0000000 \\
\hline Within Groups & 0.0294 & 12 & 0.00245 & & \\
\hline Total & 1.267711111 & 17 & & & \\
\hline
\end{tabular}

Table 6: Concentration of GnRH in different experimental groups of Puntius javanicus

\begin{tabular}{|c|c|}
\hline Experimental groups & GnRH concentration $(\mu \mathrm{g} / \mathrm{ml})$ \\
\hline $\mathrm{pH}$ 7, No toxicant (Control 1) & $1.150 \pm 0.029$ \\
\hline $\mathrm{pH}$ 7, Toxicant (Control 2) & $0.837 \pm 0.009$ \\
\hline $\mathrm{pH}$ 5, Toxicant & $0.400 \pm 0.012$ \\
\hline $\mathrm{pH}$ 6, Toxicant & $0.517 \pm 0.018$ \\
\hline $\mathrm{pH}$ 8.5, Toxicant & $1.020 \pm 0.057$ \\
\hline $\mathrm{pH}$ 9.5, Toxicant & $0.743 \pm 0.018$ \\
\hline
\end{tabular}

Table 7: Post hoc Test (LSD) Multiple Comparison

\begin{tabular}{|c|c|c|c|c|c|}
\hline (I) elisa_res & (J) elisa_res & $\begin{array}{c}\text { Mean Difference } \\
\text { (I-J) }\end{array}$ & $\begin{array}{c}\text { Std. } \\
\text { Error }\end{array}$ & Sig. & $\begin{array}{c}95 \% \text { Confidence } \\
\text { Interval }\end{array}$ \\
\hline & & & & & Lower Bound \\
\hline $\begin{array}{c}\mathrm{pH} \text { 7, No toxicant } \\
\text { (Control 1) }\end{array}$ & $\begin{array}{c}\mathrm{pH} \text { 7, Toxicant } \\
\text { (Control 2) }\end{array}$ & 0.313333 & 0.040415 & 0.000005 & 0.225278 \\
\hline & $\mathrm{pH}$ 5, Toxicant & 0.750000 & 0.040415 & 0.000000 & 0.661944 \\
\hline & $\mathrm{pH6}$, Toxicant & 0.623400 & 0.040415 & 0.000000 & 0.545278 \\
\hline & $\mathrm{pH}$ 8.5, Toxicant & 0.130000 & 0.040415 & 0.007400 & 0.041944 \\
\hline & $\mathrm{pH}$ 9.5, Toxicant & 0.406667 & 0.040415 & 0.000000 & 0.318611 \\
\hline
\end{tabular}


Fig. 3: Concentration of GnRH in different experimental groups of Puntius javanicus

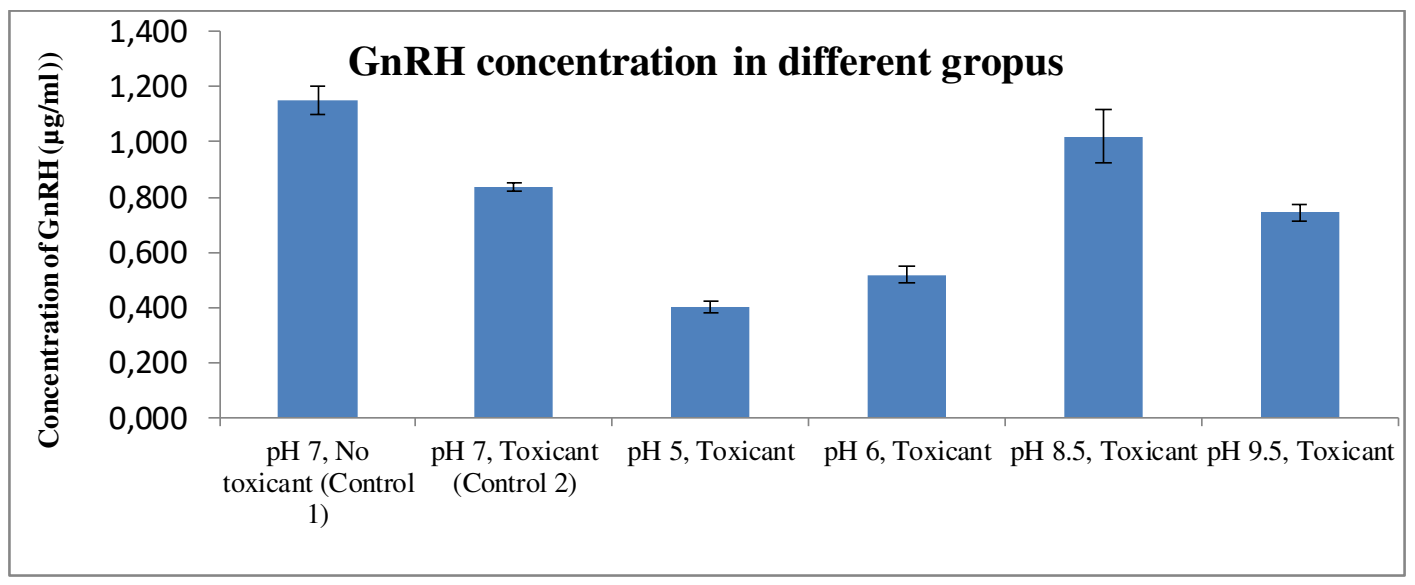

in all types of spermatogenic cells have been reported in Sarotherodon mossambicus exposed to dimecron (Lakhani and Pandey, 1985). Endosulfan also causes testicular degeneration and disappearance of sperm (Singh and Sahai, 1987). These reports are in good agreement with the findings of present study.

Ovaries of fish exposed to sub-lethal dose of cypercid 25 at $\mathrm{pH} 7$ showed increased amount of damage such as adhesion (AD) of oocytes, karyoplasmic clumping (CK), and a higher percentage of atretic (AT) cells. Nuclear retraction (NR) in oocyte III is the indication of damage in oocyte III. Sizes of all types of oocytes were decreased. Patches of macrophage (MI) is seen indicating inflammation. When fish are subjected to the acidic medium (pH 5 and $\mathrm{pH}$ 6) and in extreme basic medium ( $\mathrm{pH}$ 9.5) damages were found to be more profound. However, in $\mathrm{pH}$ 8.5 fish were found to retain normal architecture of ovaries with few abnormalities. Similar results were reported by other workers. Retardation of ovarian activity and decrease in diameter of oocyte cells due to in vivo exposure of endosulfan was reported by Pandey (1988). Damage is directly correlated with atresia which in turn correlated with a reduced fecundity (Agarwal and Singh, 1990). Follicular atresia found in present study is also reported by other workers (Molina et al., 2013; Senarat et al., 2017). The reduction of oocyte diameter due to stressor found in present study is also supported by findings of other workers (Alquezar et al., 2006; Teta and Naik, 2017). Necrosis found in the present study makes the formation of viable eggs difficult (Dutta and Maxwell, 2003). Partial disruption of the ovarian follicles, vacuolation in the cytoplasm of germinal cells, and secondary oocytes were reported in Heteropneustes fossilis exposed to BHC (Hazarika and Das, 1998). Degeneration of follicular walls, connective tissues and vacuolization in the cytoplasm of stage II and stage III oocyte was observed in Anabas testudineus treated with carbofuran 
(Chatterjee et al., 1997). This supports the present study that the oocytes were affected with a degeneration of connective tissue, disruption of follicles, and vacuolization in the cytoplasm.

One-way Anova showed significant $(p<0.001)$ difference in the concentration of $\mathrm{GnRH}$ in different experimental groups. GnRH level decreased significantly $(\mathrm{p}<0.05)$ in fishes exposed to cypercid 25 compared to control. These findings are with good agreement with findings of several researchers (Kapur and Toor, 1978; Singh and Singh, 1987; Skandhan et al., 2001; Maxwell and Dutta, 2005). GnRH level in acidic water ( $\mathrm{pH} 5$ and $\mathrm{pH}$ 6) with toxicant showed much lower concentration in comparison to the fishes exposed to the basic water ( $\mathrm{pH} 8.5$ and $\mathrm{pH} 9.5$ ) with toxicant. The GnRH concentration at $\mathrm{pH} 8.5$ with toxicant found to be almost equal to the concentration of GnRH of fishes exposed to $\mathrm{pH} 7$ without toxicant.

\section{Conclusion}

Present study documented alteration of histoarchitecture of testis and ovary and concentration of GnRH due to exposure of sub-lethal dose of cypermethrin 25\% EC. These alterations were very much influenced by alteration of $\mathrm{pH}$ of water. Fish exposed to the basic water ( $\mathrm{pH}$ 8.5) found to be somehow able to minimize the alteration induced by the toxicant in comparison with the fish exposed to acidic water (pH 5 and 6) and extreme basic water ( $\mathrm{pH}$ 9.5). Fish maintained in $\mathrm{pH} 8.5$ shows much less alterations regarding the histoarchitecture of gonads as well as concentration of GnRH.

\section{References}

Agarwal NK and Singh HR. (1990) Pre-ovulatory follicular atresia (corpora atretica) in snowtrout
Schizothorax plagiostomus (Heckel). J Anim Morpho Physio. 37: 29-33.

Aktar Md, Wasim Sengupta D and Chowdhuriy A. (2009) Impact of pesticide use in agriculture: their benefits and hazards. Interdis Toxicol. 2: 1-12.

Alquezar R, Markich SJ and Booth DJ. (2006) Effect of metal on condition and reproductive output of the smooth toadfish in Sydney estuaries, south eastern Australia. Environ Pollut. 142: 116-122.

American Public Health Association (APHA) (1985) Standard methods for the examination of water and wastewater, $16^{\text {th }}$ edn. Washington, DC, p. 1268.

Balint T, Szegletes T, Szgletes Z, Halasy K and Nemcsok K. (1995) Biochemical and subcellular changes in carp exposed to the organophosphorous methidathion and the pyrethroid deltamethrin. Aquat Toxicol. 33: 279-295.

Bradbury SP and Coates JR. (1989) Comparative toxicology of the pyrethroid insecticides. Rev Environ Contam Toxicol. 108:133-177.

Chandola M, Rathore M and Kumar B. (2011) Indigenous pest management practices prevalent among the hill farmers of Uttarakhand. Indian J Tradit Knowl. 10: 311-315.

Chatterjee S, Dutta AB and Ghosh RAD. (1997) Impact of carbofuran in the oocyte maturation of catfish, Heteropneustes fossilis (Bloch). Arch Environ Contam Toxicol. 32: 426-430.

Das PG, Luther V, Jeewaprada PN and Veeraiah K. (1999) Toxicity and effect of cypermethrin 25\% EC on biochemical constituents of freshwater teleost Channa punctatus. J Ecotoxicol Environ Monit. 9: 197-203.

Dede EB and Kaglo HD. (2001) Aqua-toxicological effects of water soluble fractions (WSF) of diesel fuel on $O$. niloticus fingerlings. J Appl Sci Environ Manage. 5: 93-96.

Ebrahimi M and Taherianfrad M (2011) The effect of heavy metal exposure on reproductive system of cyprinid fish from Kor River. Iran J Fish Sci. 10: 13-26.

Ernst I, Whittin ID, Corneillie S and Talbot C (2005) Effect of temperature, salinity, desiccation and chemical treatments on egg embryonation and hatching success of Benedenia seriolae (Monogenea: Capsalidae), a parasite of farmed Seriola spp. J Fish Dis. 28: 157-164.

Gerbron M, Geraudie P, Fernandes D, Rotchell JM, Porte C and Minier C. (2014) Evidence of altered fertility in female roach ( Rrutilus rutilus) from the river Seine (France). Environ Pollut. 191: 58-62. 
Gilliom RJ, Barbash JE, Crawford GG, Hamilton PA, Martin JD, Nakagaki N, Nowell LH, Scott JC, Stackelberg PE, Thelin GP and Wolock DM. (2007) The quality of our nation's waters: Pesticides in the nation's streams and ground water, 1992-2001. Chapter 1, p. 4. US Geological Society.

Gupta SK, Pal AK, Sahu NP, Saharan N, Mandal SC, Chandra Prakash, Akhtar MS and Prusty AK (2012) Dietary microbial levan ameliorates stress and augments immunity in Cyprinus carpio fry (Linnaeus, 1758) exposed to sub- lethal toxicity of fipronil. Aquacult Res. 45: 893-906.

Gupta SK, Pal AK, Sahu NP, Jha AK, Akhtar MS, Mandal SC, Das P and Prusty AK (2013) Supplementation of microbial levan in the diet of Cyprinus carpio fry (Linnaeus, 1758) exposed to sub-lethal toxicity of fipronil: effect on growth and metabolic responses. Fish Physiol Biochem. Doi: 10.1007/s10695-0139805-7.

Herzig A and Winkler H. (1986) The influence of temperature on the embryonic development of three cyprinid fishes, Abramis barma, Chalcalburns chalcoidesmento and Vimba vimba. J Fish Biol. 28: 171-181.

Hinckley S. (1990) Variation in egg size of walleye Pollock Theragra chalcogramma with a preliminary examination of egg size on larval size. Fish Bull. 88: 471-483.

Ikuta K, Shikama T, Oda S and Okumoto N. (1992) Acid tolerance of eyed embryos and larvae in salmonid fishes. Bull Natl Res Inst Aquacult 21: 39-45.

Ikuta K and Kitamura S. (1995) Effects of low pH exposure of adult salmonids on gametogenesis and embryo development. Water Air Soil Poll. 85: 327-332.

Kapur K, Kamaldeep K and Toor HS. (1978) The effect of fenitrothion on reproduction of a teleost fish, Cyprinus carpio communis Linn: a biochemical study. Bull. Environ. Contam. Toxicol. 20, 438-442.

Khan NY. (1983) An assessment of the hazard of synthetic pyrethroid insecticides to fish and fish habitat. In: Pesticide chemistry: Human Welfare and the Environment, (eds.) Mixamoto J. and Kearney P.C., Proceeding 5th Intern Congress Pesticide Chemistry, Kyoto, Japan, Oxford, U.K. pp. 437-450.

Khare A and Singh S. (2002) Impact of malathion on protein content in the freshwater fish Clarias batrachus. J Ecotoxicol Environ Monot. 12: 129-132.

Kumari R, Singh RK, Khanna YP and Sharma B (1997) Carbofuran induced stress mediated syndromes in Clarias batrachus. In: Proceedings Intern Conference Industrial Pollution Control Technol., pp 113-119.
Lal B. (2007) Pesticide-induced reproductive dysfunction in Indian fishes. Fish Physiol Biochem. 33: 455-462.

Larid LM and Oswald RL. (1975) A note on the use of benzocaine (Ethyl-P-Aminobenzoate) as a fish anaesthetic. Fish Manage. 6: 92-94.

Lakhani L and Pandey AK (1985) Effect of dimecron stress on testis of Saratherodon mossumbicus. Comp. Pysiol Ecol. 10: 171-175.

Mardich A, Bottero S, Benfenati E, Cevasco A, Enatico C, Maggioni S, Massari A, Pedemonte F and Vigano L. (2007) In vivo exposure of carp to graded concentrations of bisphenol A. Gen Comp Endocrinol. 153: 15-24

Maxwell LB and Dutta HM. (2005) Diazinon-induced endocrine disruption in bluegill sunfish, Lepomis macrochirus. Ecotoxicold Environ Saf. 60: 21-27.

McComic JH, Stokes GN and Hermanataz RO. (1989) Oocyte atresia and reproductive success in fathead minnows (Pimephales promelas) exposed to acidified hard water environments. Arch Environ Contam Toxicol. 18: 204-207.

Mekkawy IA and Hassan AA. (2011) Some reproductive parameters of Synodontis schall (Bloch and Schneider, 1801) from the river Nile, Egypt. J Fish Aquat Sci. 6: 456-471.

Metcalfe CD, Metcalfe TL and Kiparissis Y. (2001) Estrogenic potency of chemicals detected in sewage treatment plant effluents as determined by in vivo assays with Japanese medaka (Oryzias latipes). Environ Toxicol Chem. 20: 297-308.

Mishra D, Srivastav S, Srivastav SK and Srivastav Ajai K. (2002) Toxicity and behavioural responses of a freshwater catfish, Heteropneustes frossilis to a synthetic pyrethroid (cypermethrin). J Adv Zool. 23: 39-42.

Molina AM, Lora AJ, Blanco A, Monterde JG, Ayala N and Moyano R. (2013) Endocrine active compound evaluation: qualitative and quantitative histomorphological assessment of zebra fish gonad after bisphenol-A exposure. Ecotoxicol Environ Saf. 88: 155-162.

Nagidlo RT. (2013) Impact of pesticides and fertilizers on soil, tail water and groundwater in three vegetable producing areas in the Cordillera Region, Norhern Philippines. Am J Exp Agric. 3:, 780-793.

Ojaveer H, Tomkiewicz J, Arula T and Klais R (2015) Female ovarian abnormalities and reproductive failure of autumn-spawning herring (Clupea harengus membras) in the Baltic Sea. ICES J Mar Sci. 72: 2332-2340. 
Pandey AK and Shukla L. (1980) Effect of BHC an insecticide on the testicular histology in Tilapia mossumbica. Geobios 7: 251-253.

Pandey AC. (1988) Impact of Endosulfan (Thiodan EC 35 ) on behavior and dynamics of oocyte development in the teleostean fish Colisa fasciatus. Ecotoxicol Environ Saf. 15: 221-225.

Rao LM and Ramaneshwari K. (2000) Effect of sublethal stress of endosulfan and monocrotophos on the biochemical components of Labeo rohita, Mystus vittatus and Channa punctata. Ecol Env Cons. 6: 289-296.

Ruby SM, Idler DR and So YP. (1987) Changes in plasma, liver and ovary vitellogenin in land-locked atlantic salmon following exposure to sublethal cyanide. Arch Environ Contam Toxicol. 16: 507-510.

Sanchez-Fortun S and Barahona MV. (2005) Comparative study on the environmental risk induced by several pyrethriods in estuarine and freshwater invertebrate organisms. Chemosphere 59: 553-559.

Senarat S, Jiarungkoorskul W and Kettratad J. (2017) Ovarian histology and reproductive health of short mackerel, Rastrelliger brachysoma (Bleeker, 1851), as threatened marine fish in Thailand. Songklanakarin J Sci Technol. 39: 225-235.

Shukla L, Srivastava A, Merwani D and Pandey AK. (1984) Effect of sub-lethal malathion on ovarion histophysiology in Sarotherodon mossanbicus. Comp Physiol Eco. 27:13-17.

Singh S and Singh TP. (1987) Evaluation of toxicity limit and sex hormone production in response to Cythion and BHC in the vitellogenic catfish Clarias batrachus. Environ Res. 42: 428-488.

Skandhan KP, Sahab Khan P and Sumangala B. (2001) DDT and male reproductive system. Res J Environ Toxicol. 5: 76-80.

Smith TM and Stratton GM. (1986) Effects of synthetic pyrethroid insecticides on non-target organisms. Residue Rev. 97: 93-119.
Sokal RZ, Maddind CE and Swerdloff RS. (1985) Lead toxicity and the hypothalamic pituitary testicular axis. Biol Reprod. 33: 722-728.

Sprague JB (1969) Measurement of pollutant toxicity to fish. I. Bioassay methods for acute toxicity. Water Res. 3: 793-821.

Srivastav Ajai K. Agarwal K, Kumar A, Prasad M and Suzuki N. (2020) Acute toxicity of mercuric chloride to the freshwater catfish, Heteropneustes fossilis. Intern J Zool Invest. 6: 301-305.

Teta C and Naik YS. (2017) Vitellogenin induction and reduced fecundity in zebrafish exposed to effluents from the city of Bulawayo, Zimbabwe. Chemosphere 167: 282-290.

Tiffany LL, David H, Jenifer K, McIntyre and Nathaniel L. (2009) Effect of water hardness, alkalinity and dissolved ortganic carbon on the toxicity to the lethal line of developing fish. Environ Toxicol Chem. 28: 1455-1461.

Tudi M, Huada DR, Li Wang, Jia L, Ross S, Des C, Cordia C and Dung TP. (2021) Agriculture development, pesticide application and its impact on the environment. Int J Environ Res Public Hlth. 18: 1112. https://doi.org/10.3390/ijerph18031112.

Wilson JN. (1956) Effects of turbidity and silt on aquatic life. In: Biological problems in water pollution, (ed.) Tarzwell C.M., U.S. Dept. Health, Educ., and Welfare, Cincinnati, $\mathrm{OH}$.

Yokota H, Tsuruda Y and Medala M. (2000) Effect of bisphenol A on early life stage in Japanese medaka (Oryzias latipes). Environ Toxicol Chem. 19: 1925-1930.

Zhang Q-F, Li YW, Liu ZH and Chen QL. (2016) Exposure of mercuric chloride induces developmental damage, oxidative stress and immunotoxicity in zebrafish embryos-larvae. Aquat Toxicol. 181: 76-85.

Zutshi B and Murthy PS. (2001) Ultrastructural changes in testis of gobiid fish Glossogobius giuris (Ham.) induced by fenthion. Ind J Exp Biol. 39: 170-173. 